\title{
A Case of Rheumatoid Arthritis with Strongyloides stercoralis Hyperinfection
}

\section{Strongyloides stercoralis Hiperinfeksiyonlu Bir Romatoid Artrit Olgusu}

\author{
(1) Selçuk Nazik ${ }^{1}$, (1) Fatih Yıldız
}

${ }^{1}$ Kahramanmaraş Sütçü İmam University Faculty of Medicine, Department of Infectious Disease and Clinical Microbilogy, Kahramanmaraş, Turkey

${ }^{2}$ Kahramanmaraş Sütçü İmam University Faculty of Medicine, Department of Rheumatology, Kahramanmaraş, Turkey

\begin{abstract}
The patient was a 83-year- old male who worked as a farmer. He had complaints of weight loss, abdominal pain and joint pains for almost 5 months. Twenty days ago, the patient was checked at another hospital for complaints of occasional coughing and bloody sputum. He was treated with a diagnosis of pneumonia. His respiratory complaints were reduced, but there was no relief of his ongoing abdominal pain. Gastroduodenoscopy and colonoscopy were performed to examine for possible etiologies of continuous abdominal pain. Biopsies were taken from duodenal bulbus and second duodenal segment. Intense eosinophilic leukocyte infiltration and Strongyloides stercoralis larvae were observed in pathologic examination. The patient was successfully treated with albendazole $2 \times 400 \mathrm{mg} /$ day for $7+7$ day.
\end{abstract}

Keywords: Rheumatoid arthritis, Strongyloides stercoralis, hyperinfection

Öz

Çiftçi olarak çalışan 83 yaşındaki erkek hastanın yaklaşık beş aydır kilo kaybı, karın ağrısı ve eklem ağrıları şikayeti vardı. Yirmi gün önce, hasta ara sıra öksürük ve kanlı balgam şikayetleri nedeniyle başka bir hastaneye başvurdu. Pnömoni tanısı ile tedavi edildi. Solunum yakınmaları azalmasına rağmen hastanın karın ağrısı şikayeti düzelmedi. Hastaya karın ağrısının olası etiyolojileri için gastroduodenoskopi ve kolonoskopi yapıld. Biyopsiler duodenal bulbus ve duodenumun ikinci kısmından alındı. Patolojisinde yoğun eozinofilik lökosit enfiltrasyonu ve Strongyloides stercoralis larvaları gözlendi. Hasta albendazol 2x400 mg/gün, 7+7 gün tedavisiyle başarılı bir şekilde tedavi edildi.

Anahtar Kelimeler: Romatoid artrit, Strongyloides stercoralis, hiperinfeksiyon

\section{INTRODUCTION}

Strongyloides stercoralis is an intestinal helminth that is transmitted from the soil, therefore it may affect millions of people. It was first identified in the stool samples of soldiers who had gastrointestinal complaints and diarrhea after returning from the war in Vietnam in 1876. Although S. stercoralis infection is seen in tropical and subtropical regions, low socioeconomic status is one of the most important reasons for the acquisition of primary disease $(1,2)$.

Transmission of $S$. stercoralis to human is mainly by penetration of filariform larvae through the skin while contacts with the soil. There may be complaints of pruritus and erythema on the skin near the entrance site of the larvea. This helminth can migrate to the lungs and cause different clinical pictures in relation to the immunological status, which may range from no relevant symptoms to a patient with pneumonia. Main gastrointestinal symptoms are resistant diarrhea ( $\geq 5$ times/day) that is usually accompanied by abdominal pain and meteorism $(3,4)$.

In humans, hyperinfection and disseminated infection of $S$. stercoralis have been reported to occur in the presence of comorbid conditions such as chronic liver disease, cirrhosis, peptic ulcer, chronic obstructive pulmonary disease, and drug-induced

Received/Geliş Tarihi: 14.11.2018 Accepted/Kabul Tarihi: 3.03.2020

Address for Correspondence/Yazar Adresi: Selçuk Nazik MD, Kahramanmaraş Sütçü Imam University Faculty of Medicine, Department of Infectious Disease and Clinical Microbilogy, Kahramanmaraș, Turkey Phone/Tel: +90 5055019161 E-mail/E-Posta: dr.selcuknazik@hotmail.com ORCID ID: orcid.org/0000-0003-0587-0104 
immunosuppression such as corticosteroid, vinca alkaloids, cyclosporin, azathioprine, bleomycin $(5,6)$.

Here we aimed to present a patient with rheumatoid arthritis that was diagnosed as $S$. stercoralis infection with the demonstration of larvae in duodenal biopsy.

\section{CASE REPORT}

The patient was a 83 years old male who works as a farmer. He had complaints of weight loss, abdominal pain and joint pains for almost 5 months. Twenty days ago, the patient was checked at another hospital for complaints of occasional coughing and bloody sputum. He was treated to having pneumonia. His respiratory complaints were reduced, but there was no relief of his ongoing abdominal pain, corticosteroid therapy (prednisolone at $7.5 \mathrm{mg} /$ day) was also initiated with the suspicion of respiratory distress.

The patient was referred to us in the rheumatology department where he was admitted because of accompanying pain and swelling in his joints. Physical examination showed swelling on the left elbow, tenderness and swelling of both wrists and metocarpophalangeal joints. Body temperature: $36.2{ }^{\circ} \mathrm{C}$, pulse rate: 68 beats/min, blood pressure: 110/70 mm-Hg. Other system examinations were normal. Complete blood count of the patient was; $12.7 \mu \mathrm{L}$ white blood cells, hemoglobin $11.6 \mathrm{~g} /$ dL, hydrochlorothiazide: $34.7 \%$ and platelets $233 \mu \mathrm{L}$. Peripheral spread was $61.9 \%$ neutrophil, $12.4 \%$ lymphocyte, $20.4 \%$ eosinophil, $5 \%$ monocyte, $0.3 \%$ basophil.

The rheumatoid factor, antinuclear antibody and anti-cyclic citrullinated peptide tests performed in relation to the joint sympthoms were negative. Rheumatoid arthritis (RA) 2010 EULAR/ACR classification criteria applied and found 6 points. periarticular osteopenia, soft tissue swelling, and narrowing of the radiocarpal joint were present on hand X-ray. With these findings, the patient was diagnosed with seronegative RA.

Abdominal ultrasonography revealed hepatosteatosis and no parasites were seen in stool and and phlegm samples examination. Thus, gastroduodenoscopy and colonoscopy were performed to examine for possible etiologies of continuous abdominal pain. Duodenitis, bulbitis, antral gastritis and colonic diverticula were detected. Duodenal bulbus and $2^{\text {nd }}$ duodenal segment were extremely hyperemic and granular in appearance. Biopsies were taken from these regions. Pathology; biopsies were first stained with hematoxylin and eosin, intense eosinophilic leukocyte infiltration and intraepithelial nematodes were observed (Figure 1A, B). Biopsies were stained with Periyodik asit Schiff and Alcian Blue as advanced staining technique and $S$. stercoralis larvae

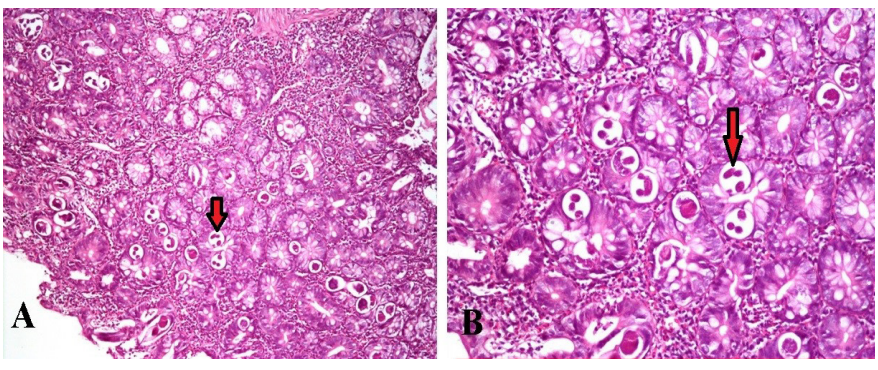

Figure 1. Intraepithelial nematode larvae in duodenal biopsy specimen A) Hematoxylin and eosin X100, B) Intraepithelial nematodes are indicated by red arrows (Hematoxylin and eosin X200) were observed. Prior corticosteroid therapy, eosinophilic lung symptoms and resistant gastrointestinal complaints led to a first suggestion of $S$. stercoralis hyperinfection. The patient was treated with albendazole $2 \times 400 \mathrm{mg}$ for seven days. Another cure of albendazole was also given after an interval of 2 weeks. The patient had full recovery with no gastrointestinal complaints and his eosinophil counts were measured within normal range.

\section{DISCUSSION}

The main risk factors that facilitate the transmission of $S$. stercoralis infection are, dealing with soil as a profession where the larvae are located and, defects of the skin integrity (6). The fact that our patient is a farmer makes him prone to infection with larvae. The classical autoinfective cycle of $S$. stercoralis is the transition of the larvae to the lungs and the gastrointestinal tract after entering through the skin of the host. In hyperinfection, this cycle is exaggerated, with increased parasite load and frequency (7). Hemoptysis and respiratory distress in our patient suggested parasite migration to the lungs. The use of corticosteroids to treat respiratory distress also caused drug-induced immunosuppression. In addition, weight loss, abdominal pain and meteorism complaints of the patient suggested hyperinfection.

Eosinophils play an important role in the immune response to parasitic infections. Therefore, it is important to investigate patients with eosinophilia for parasitic diseases. There are differences in the data of the literature regarding to the eosinophil ratios of $S$. stercoralis infected patients. In one study, it was reported that the rate of eosinophils rises up to $70 \%$ in the first period and it maintains at $5-15 \%$ in the later period of the disease (8). In an HIV (+) case reported by Lessnau et al. (9), S. stercoralis infection was accompanied by a relatively lower eosinophil as 20.4\%. Despite the use of corticosteroids, eosinophilia required a search for a parasitic infection in our patient. Decrease in eosinophil levels during treatment was assessed in response to proper treatment. The absence of parasites in stool examination does not exclude the diagnosis of S. stercoralis. Direct stool examination should be repeated three times. If still negative, the stool should be re-examined with lugol and formaldehyde ether precipitation method (10). In the study by Ashiri et al., acase of strongyloidiasis in a 58-year-old female with a history of RA and type 2 Diabetes Mellitus was reported. The patient was treated with corticosteroids for RA. After the treatment patient was presented with abdominal pain and gastrointestinal bleeding. In the fourth direct stool examination, rhabditiform larva of $S$. stercoralis was reported (11). In anaother study by Altıntop et al., a 68 year old woman had bronchial asthma and also RA. She was received immunusupressive agents including methotrexate (15 mg/week) and steroids (deflazacort $5 \mathrm{mg}$ /day). She was afebrile, had rhonchi and mild epigastric tenderness. Stool and sputum parasitological examinations were positive for $S$. stercoralis larvae (12). In this study, larvae were not seen although stool were sent for examination three times. The diagnosis was made on pathological basis thanks to the biopsy specimen taken from the duodenum. Lugol and formaldehyde ether precipitation techniques could have been included in the diagnostic approach, were not used for this patient. Ivermectin is recommended as the primary treatment option Strongyloides infections $(12,13)$. However, this drug is not available in our country. In addition, different treatment options such as pyrvinium pamoate, thiabendazole, albendazole can be 
effective. After we analyzed the cases that were presented in the literature, we saw that albendazole treatment was commonly and effectively used $(11,12)$. However, different protocols were applied for the duration of this treatment. Albendazole cures were given at different durations, such as 3-7-10-14 days. Recurrences were seen in patients continuously treated for 14 days. A regimen of 7+7 days, with a 1-3 week interval between treatment days, was tried and successful results were obtained $(5-7,10,14)$. In this case, the patient was successfully treated with $7+7$ day treatment regimen. As it is understood, repeated intermittent cures increase the chance of success for treating strongyloidosis.

The limitation of our study is the lack of diagnostic molecular tests in our case.

\section{CONCLUSION}

As a result, parasitologic etiologies should be kept in mind while investigating patients with eosinophilia, hemoptysis, weight loss and abdominal pain, especially for those under immunosuppressive treatment.

\section{ACKNOWLEDGMENT}

Thank you for contributions to the Çukurova University Faculty of Medicine, Department of Pathology and Department of Parasitology.

\section{* Ethics}

Informed Consent: Written informed consent was obtained from the patient.

Peer-review: Internally peer-reviewed.

\section{* Authorship Contributions}

Surgical and Medical Practices: F.Y., S.N., Concept: F.Y., S.N., Design: F.Y., S.N., Data Collection or Processing: F.Y., S.N., Analysis or Interpretation: F.Y., S.N., Literature Search: F.Y., S.N., Writing: F.Y., S.N.

Conflict of Interest: No conflict of interest was declared by the authors.

Financial Disclosure: The authors declared that this study received no financial support.

\section{REFERENCES}

1. Weinstein D, Lake-Bakaar G. Strongyloides stercoralis infection presenting with severe 75 malabsorption and arthritis in an immune competent host. Internet J Rheumatology 2006;2.

2. Olsen A, Van Lieshout L, Marti H, Polderman T, Polman K, Steinmann $\mathrm{P}$, et al. Strongyloidiasis - the most neglected of the neglected tropical diseases? Trans R Soc Trop Med Hyg 2009;103:967-72.

3. Yerra S, Yarra P. Case report of a computerized tomography sign in Strongyloides stercoralis infection. Int Med Case Rep J 2017;10:219-22.

4. Tsai HC, Lee SS, Liu YC, Lin WR, Huang CK, Chen YS, et al. Clinical manifestations of strongyloidiasis in southern Taiwan. J Microbiol Immunol Infect 2002;35:29-36.

5. Siddiqui AA, Berk SL. Diagnosis of Strongyloides sterocoralis infection. Clin Infect Dis 2001;33:1040-7.

6. Culha G, Savaş L, Onlen Y. Strongyloides stercoralis in a patient complaining of chronic diarrhea. Turkiye Parazitol Derg 2006;30:293-5.

7. Kassalik M, Mönkemüller K. Strongyloides stercoralis hyperinfection syndrome and disseminated disease. Gastroenterol Hepatol (N Y) 2011;7:766-8.

8. Loutfy MR, Wilson M, Keystone JS, Kain KC. Serology and eosinophil count in the diagnosis and management of strongyloidiasis in a nonendemic area. Am J Trop Med Hyg 2002;66:749-52.

9. Lessnau KD, Can S, Talavera W. Disseminated Strongyloides stercoralis in human immunodeficiency virus-infected patients. Treatment failure and a review of the literature. Chest 1993;104:119-22.

10. Ekmekci ÖÖ, Tahmaz M, Altıparmak S, Gülaçtı G, Ergen AK, Kumbasar AB, et al. Strongyloidosis caused Loeffler's syndrome in an immunosuppressed patient who uses cronic steroid. Turkiye Parazitol Derg 2013;37:55-7.

11. Ashiri A, Beiromvand M, Khanzadeh A. Strongyloides stercoralis infection in a patient with rheumatoid arthritis and type 2 diabetes mellitus: a casebased review. Clin Rheumatol 2019;38:3093-8.

12. Altintop L, Cakar B, Hokelek M, Bektas A, Yildiz L, Karaoglanoglu M. Strongyloides stercoralis hyperinfection in a patient with rheumatoid arthritis and bronchial asthma: a case report. Ann Clin Microbiol Antimicrob 2010;9:27.

13. Lewthwaite P, Gill GV, Hart CA, Beeching NJ. Gastrointestinal parasites in the immunocompromised. Curr Opin Infect Dis 2005;18:427-35.

14. Yllmaz I, Cağlar B, Akay BN, Alkız G, Boyvat A, Akyol A. [Strongyloides stercoralis hyperinfection syndrome in a patient with Behçet's Disease]. Turkiye Parazitol Derg 2013;37:139-42. 